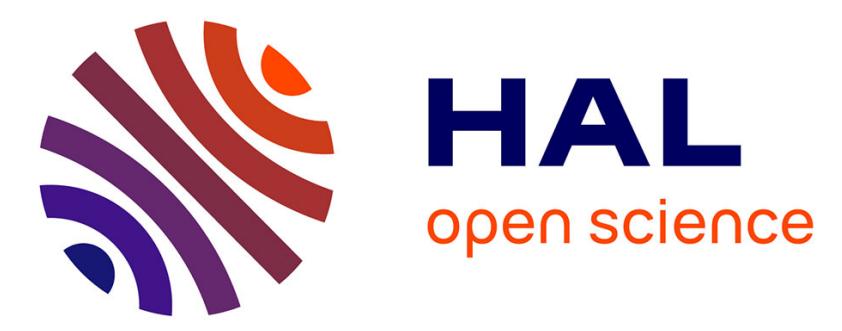

\title{
The contribution of urban food policies toward food security in developing and developed countries: A network analysis approach
}

\author{
Rosalia Filippini, Chiara Mazzocchi, Stefano Corsi
}

\section{To cite this version:}

Rosalia Filippini, Chiara Mazzocchi, Stefano Corsi. The contribution of urban food policies toward food security in developing and developed countries: A network analysis approach. Sustainable Cities and Society, 2019, 47, 10.1016/j.scs.2019.101506 . hal-02907087

\section{HAL Id: hal-02907087 \\ https://hal.inrae.fr/hal-02907087}

Submitted on 22 Oct 2021

HAL is a multi-disciplinary open access archive for the deposit and dissemination of scientific research documents, whether they are published or not. The documents may come from teaching and research institutions in France or abroad, or from public or private research centers.
L'archive ouverte pluridisciplinaire HAL, est destinée au dépôt et à la diffusion de documents scientifiques de niveau recherche, publiés ou non, émanant des établissements d'enseignement et de recherche français ou étrangers, des laboratoires publics ou privés.

\section{다)(1) $\$$}

Distributed under a Creative Commons Attribution - NonCommerciall 4.0 International 
The contribution of Urban Food Policies toward food security in developing and developed countries: a network analysis approach

Rosalia Filippini ${ }^{1,2 *}$

${ }^{1}$ Department of Health, Animal Science and Food Safety - University of Milan,

Via Celoria, 2, Milan, (Italy)

${ }^{2}$ UMR Territoire, INRA \& AgroParisTech,

9 Avenue Blaise Pascal, 63178 Aubière, France

rosalia.filippini@unimi.it

* Corresponding author

Chiara Mazzocchi ${ }^{3}$

${ }^{3}$ Department of Agricultural and Environmental Sciences - Production, Landscape, Agroenergy University of Milan,

Via Celoria, 2, Milan, (Italy)

chiara.mazzocchi1@unimi.it

Stefano Corsi ${ }^{3}$,

${ }^{3}$ Department of Agricultural and Environmental Sciences - Production, Landscape, Agroenergy University of Milan,

Via Celoria, 2, Milan, (Italy)

stefano.corsi@unimi.it

Funding: This research did not receive any specific grant from funding agencies in the public, commercial, or not-for-profit sectors. 
1 The contribution of Urban Food Policies toward food security in developing and developed countries: a network analysis approach

3 Abstract

4 Cities around the world face new challenges of food security, and are developing urban food policies. Their

5 objective is to integrate hunger problems with the aims of a food system based on environmental, economic 6 and social sustainability. In this study a comparative analysis of the urban food policies' actions is conducted, 7 as envisaged in cities around the world. The methodology is based on the community detection method through network analysis, in which the number of actions cities have in common defines their adjacency in the network.

9 The Milan Urban Food Policy Pact, which is a unique city platform worldwide, was used to select the cities 10 and to analyse the actions in them, as classified into six main topics: ensuring and enabling an environment for 11 effective action; sustainable diets and nutrition; social and economic equity; food production; food supply and distribution; and food waste. Three clusters are thus identified: i) agriculture for food security; ii) governance and food economy; and iii) sustainable and healthy consumption. This research provides a description of the main focuses of current policies, and their main political differences. The study may therefore also help improve future development.

16 Key-words: urban food policy, Milan Urban Food Policy Pact, Network analysis, Food security

\section{Highlights}

- Food security is an urban issue

- Specific local-based policies are in place around the world

- A network analysis was conducted

- Agriculture, governance and healthy nutrition are the main political concerns 


\section{Introduction}

2 The continuous increase in population has led to the rapid expansion of urban settlements: the global 3 population in 2050 will be nine billion, with individuals concentrated in metropolitan areas (FAO, 2015).

4 People living in cities are net food consumers, in comparison to the rural population that is totally or partially involved in agricultural production. Thus, the higher the level of urbanization, the higher the proportion of the non-agricultural population, and cities depend on food provision from the rural areas.

The most common definition of food security is that "Food security exists when all people, at all times, have physical and economic access to sufficient, safe and nutritious food to meet their dietary needs and food preferences for an active and healthy life". This was proposed in 1996 at the World Food Summit (WFS), which aimed to focus international attention on the issue of hunger. At a global level, the number of undernourished people has declined in the last decade by about 167 million (FAO, 2015), but about 793 million people still suffer from hunger (FAO 2015) and many millions of urban adults regularly fall short of the 2,100 kilocalories recommended for a healthy, active life. International organizations and the scientific literature agree that the issue of food insecurity is and mainly will be an urban makers and planners (Maxwell, 1999). In developing countries, food security issues are frequently related to chronically insufficient access to food takes place in polluted environments that involve health risks (De Bon et al., 2010) and lack legal status (Bryld, 2003). Recently peri-urban agriculture has also been considered to be significant in the feeding of developing cities, and projects have been developed to expand peri-urban agriculture production to address the societal shifts caused by rapidly changing demographics (WVC, 2013). The adverse climate conditions and natural 
countries, and exacerbate the problems of food production and availability. This problem is more severe in the most urbanized areas such as the so-called megacities, which also suffer from a lack of land availability and are widespread in the Asian countries.

Developing countries are also severely affected by volatility in global food prices. After the food crisis of 2007-2008, when the need for fertile land for food production became evident, the fear of politically unstable conditions due to the dependence on volatile food imports generated much of the immediate demand for land in that period. The so called "rush for land" was caused by investors worldwide acquiring land for agriculture and resource extraction, much of it in the global South, increasing the food insecurity of these countries (Mazzocchi et al., 2018). Urban residents are also more disadvantaged than rural residents because they are dependent on food markets and net consumers, so are more vulnerable to potential price volatility (Szabo, 2016). This dependence means that urban dwellers often use informal food systems, which may involve low quality food and a lack of hygiene during food preparation and sale (Szabo, 2015, Obosu-Mensa, 2002). Particularly in the megacities of Asia, the demand for food is extremely high and concentrated, and urban agriculture is not applicable because of the lack of or limited agricultural areas.

Last, developing countries face many challenges related to political instability and corruption (Szabo, 2016), and in some cases these can lead to civil war, with cities often being the most vulnerable places in which these issues arise.

In developed countries different forms of urban poverty and food insecurity can occur. In the US, the number of people affected by limited food supplies increased from 33 million in 2001 (Brown and Carter, 2003) to 45 million in 2010 (Besthorn, 2013), thus affecting at least 12\% of households (Macias, 2008). Between 2009 and 2012 in Europe, an increase of $75 \%$ in the number of people dependent on food assistance was observed (International Federation of Red Cross and Red Crescent Societies 2013). Low-income neighborhoods within cities in the US are also becoming 'food deserts' with few grocery stores and more fast food restaurants (Segal, 2010).

Thus, there is also a debate in the literature about the North, as recently the emerging focus on food access has been recognised, and the spatial inequities in food retail and questions of access have been identified (Battersby, 2013). In 2013, an initiative was implemented involving Michelle Obama joining forces with Wal- 
1 Mart to promote healthy habits and to tackle child obesity in US cities, and to combat the phenomenon of food

2 deserts Wal-Mart also opened outlets in suburban districts of large cities.

3 Scholars therefore agree that including food security in urban policies is thus necessary to support sustainable

4 urban development (Smith, 1995). Thus, the benefits of public interventions in urban food security planning

5 require a sufficient capacity in public institutional networks so multiple positive effects can result (Coppo et 6 al., 2017).

\section{$7 \quad 1.1$ Food policies: how to address the main issues}

8 In several cities political concerns about food security have led local institutions to develop urban food policies 9 (UFPs) (Marsden and Sonnino, 2012). According to Raja et al. (2008, pp. 25), UFPs should be "comprehensive plans provide a roadmap for the future growth of a community. Inclusion of food issues in a comprehensive plan ensures that, along with ensuring adequate housing, jobs, transportation, etc., a community is positioned to have a well-functioning community food system in the future-one that provides access to healthful and affordable foods for all residents". Thus, the aim of UFPs should be not only to simply provide enough food to everyone, but to ensure this provision is within the limits of environmental, economic, and social sustainability (Sonnino, 2014), thus addressing the currents constraints of the urban food system (Coppo et al., 2017).

Authors have identified and addressed several requirements for the proper design and implement of UFPs, and based their analyses on initial UFP examples, highlighting critical issues in their implementation.

The analysis of UFP had specifically identified that actual food production must be reconnected with the needs of the urban food system. According to authors, analysing exactly what is produced near to a city is the first step in developing a secure and sustainable urban food system (Filippini et al., 2018; Morrison et al., 2011). Zasada et al. (2017) point out that particularly in metropolitan areas, is necessary to consider the regional context, where in addition to encouraging food production, organizational innovations aimed at shorter food supply chains are fundamental for the re-connection with urban areas and must be acknowledged in research and policy. The most recent literature elaborates on this subject by extending the contribution of Wiskerke (2009) on the concept of "new food geographies", based on the triangular conceptual framework of Short Food Supply Chains, the Revaluation of Public Procurement and Urban Food Strategies. 
1 Urban and Periurban agriculture can play a very significant role in providing food for cities and can contribute

2 to urban food security. Siegner et al. (2018) note that studies on urban food have proposed that local institutions

3 should provide a framework to address the production issues of the city (Peter et al., 2008, Horst et al., 2017

4 McClintock et al., 2013) and have focused on the production potential of urban land. UFPs can regulate UA through a) using enabling ordinances, for example land use designations and zoning ordinances; b) the regulations on urban agriculture production, for example on backyard animals; and c) the implementation of

7 fiscal policy instruments, such as tax abatement (Meenar et al., 2017),

8 A main issue regarding UFPs is the debate over how we eat and modes of consumption (Lang and Barling, 9 2012), and that we cannot reduce the urban food question to a narrow nutritional agenda (Morgan, 2015: 2). Local nutritional problems involve economic equity and social justice, and should be addressed by "urban nutritional interventions", as a precondition for developing specific policies (Dixon et al., 2007). These interventions should be based on a comprehensive and integrated approach that combines infrastructure improvement, health promotion, and community participation. Routine assessments of the effects of the locations and accessibility of food retail outlets on health equity can be of benefit to urban design and planning, and actions that may change the modes of transportations and distributions can be identified (Friel et al., 2007). Specific actions should also account for food safety protocols specific to the context; better control and governance of the local activities of multinational supermarkets and food suppliers; and initiatives for food self-reliance. (WHO, 2008). The need for specific UFPs in megacities is one of the most challenging goals, but very few efforts have been currently made.

Concerns are also raised about the need to include the "exchange nodes" of food supply, such as food platforms, distributors, groceries, and improving food transportation (Sonnino, 2014, Feenstra, 2007). UFPs can support the development of innovative distribution systems that can work side by side with large retail systems, using technological innovation as one of the leverages enhancing urban sustainability and thus making urban food policies more effective (Martin et al., 2018). As the responsibility of local public bodies, public food procurement in schools and health centers is regarded as one of the first areas in which the distribution of food can be developed towards sustainable modes of production and consumption (Viljoen and Wiskerke, 2012; Moragues-Faus and Morgan, 2015). For institutions, the inclusion of local and organic food is often used to encourage the sustainability of public food procurement. However, empirical studies have shown that it is local 
1 alliances of public bodies, private companies and families that effectively lead to change in the organization

2 of the food supply, improving the level of sustainability (Filippini et al., 2018).

3 Governance is an important issue for UFPs. The responsibilities for the different components of the urban

4 food system are typically divided between various local authorities who do not work together and may make contradictory decisions. This hampers the food security of urban dwellers and thus urban sustainable development (Smith, 1995). Thus, coordinated food policy actions are required that consider the different stages in urban food supply (Smith, 1995). Studies have verified that while some cities have attempted to implement integrated strategies and are more able to include different dimensions of the agro-food system, others have simply taking food security action that is disconnected (Doernberg et al., 2016). The issues of whether and how a city government should influence and intervene in the agricultural sector currently remains unresolved in the literature, and the type and amount of resources to be used should be considered (Cohen and Reynolds, 2014). UFPs may have different frameworks, and must consider the themes and concerns developed in local areas, and herein lie the innovations of different policies (Coppo et al., 2017). To better coordinate the disparate elements of food systems, Food Policy Councils should be established that include private and public actors, to support the effectiveness of private bottom up and institutional top down initiatives (Feenstra, 2007). The topic of social justice is relevant in the literature of UFP, as the needs of certain communities should not be prioritised over others and no groups should be excluded from the policy-making processes (Cohen and Reynolds, 2014).

In urban agriculture, community gardens are often proposed as a way to ensure both social inclusion and and deepen societal inequities by benefitting better resourced organizations and the propertied class and contributing to the displacement of lower-income households. The precariousness of land access for urban agriculture is another limitation, particularly for disadvantaged communities." (pp.277).

26 To the best of our knowledge, no global review of urban food policies and plans has been conducted. The main purpose of this research is to conduct a comparative analysis of UFPs and/or the urban food actions carried out 
cities worldwide that share the same values and aims. During the Expo 2015, the MUFPP gathered together representatives of these cities to define urban policies for food security. This emerged as an international protocol, engaging 148 cities in the development of food policy systems, based on the principles of sustainability and social justice. The sample in this study has been selected from these cities.

The methodology used to establish the main trends in urban food policies and actions is based on Network Analysis. This enables the characteristics of cities to be grouped on the basis of the common policies implemented, using a person-groups approach (Borgatti and Everett, 1997). Section two describes this methodology, including the case study, data and modelling. Section three presents the results, which are discussed in Section four. Finally, Section five provides the conclusions.

\section{Methodology}

The methodology is based on community detection through network analysis. Following the person-groups approach (Borgatti and Everett, 1997) the network analysis creates associations between actors based on their similarities. Thus, the qualitative textual analysis of political discourses must be standardized using qualitative coding (Saldanha, 2009) and can then provide a standardized measurement of similarities in policy content. Consequently, clusters in the network are groups of actors which share similar ideas.

A similar approach has been proposed for analysing political discourses on climate changes (Tobin et al., 2018 ), where the network aimed to connect the relationships of the actors through the content of their policy declarations. According to the authors "the alignment of actors by common claims is essentially a relational phenomenon" (Leifeld and Haunss, 2012: 389), so social network analysis is essential to properly place them in the general debate. In this study, the network between the cities is based on an analysis of their urban food policy documents, and is created by considering the actions cities have in common. Thus, the network resulting from the analysis is based on the similarities between policies, not on the actual links between cities. The clusters created through community detection are thus groups of policies with similar actions planned. The methodology follows three main steps: first, the database was created by selecting the policies and by conducting the textual analysis and the actions coding; second, the network linking cities' policies was developed; and finally, clusters were detected and analysed.

\subsection{Sample and database}


1 The Milan Urban Food Policy Pact (MUFPP) is an international protocol subscribed to by the Mayors of 148

2 Cities worldwide (MUFPP, 2017). Initiated during Expo 2015, a major event in Milan (Italy), the MUFPP

3 engages the cities in the development of urban food systems that can contribute to improve food security and

4 sustainable development. The 148 cities that signed the MUFPP were chosen as the sample for this analysis.

5 An initial selection was conducted to consider only the cities that have effectively developed urban food

6 policies, or that have carried out specific actions relevant to urban food governance. In this phase, 32 cities

7 from the 148 were selected (Table 1). The policy documents were found through an Internet search starting

8 with the municipalities' websites and using key words such as "urban food strategy", "urban food policy",

9 "food security" and "urban food system", translated into the official languages of the city's Countries.

\begin{tabular}{|c|c|c|}
\hline City & UFP or Action/s & References \\
\hline Almere & Agromere & The RUAF Foundation, 2011 \\
\hline Amsterdam & Food \& Amsterdam; Proeftuin Amsterdam & $\begin{array}{l}\text { European Commission, 2008; } \\
\text { Gemeente Amsterdam, } 2013 .\end{array}$ \\
\hline Baltimore & Baltimore Food Policy Initiative & Baltimore City, 2014 \\
\hline $\begin{array}{l}\text { Belo } \\
\text { Horizonte }\end{array}$ & Secretaria Municipal de Abastecimento's projects & Rocha, 2016 \\
\hline Berlin & Several projects of urban agriculture & Berlin Metropolis, 2015 \\
\hline Bilbao & Several actions of food governance & MUFPP, 2016 \\
\hline Birmingham & Birmingham Food Charter & Birmingham Food Council, 2014 \\
\hline Bogotà & $\begin{array}{l}\text { Plan Maestro de Abastecimiento de Alimentos para } \\
\text { Bogotá }\end{array}$ & Alcadia Bogotà, 2008 \\
\hline Chicago & A Recipe for Healthy Places & City of Chicago, 2013 \\
\hline Ghent & Gent en Garde & Ghent Food Policy Council, 2014 \\
\hline Johannesburg & $\begin{array}{l}\text { Agriculture and Food Security priority, part of the } \\
\text { Joburg } 2040 \text { Strategy }\end{array}$ & $\begin{array}{l}\text { City of Johannesburg } \\
\text { Metropolitan Municipality, } 2011\end{array}$ \\
\hline La Paz & $\begin{array}{l}\text { Ley Municipal Autónoma No. } 105 \text { de Seguridad } \\
\text { Alimentaria de La Paz }\end{array}$ & $\begin{array}{l}\text { Ciudad de Nuestra Señora de La } \\
\text { Paz, } 2014\end{array}$ \\
\hline London & $\begin{array}{l}\text { London Food Strategy - Healthy and Sustainable } \\
\text { Food for London }\end{array}$ & $\begin{array}{l}\text { London Development Agency, } \\
2006\end{array}$ \\
\hline Lusaka & Women Groups Economical Empowerment & MUFPP, 2015b \\
\hline Madrid & Alimentando otro modelo de ciudad & Ajuntamento de Madrid, 2016 \\
\hline Melbourne & Food city: City of Melbourne Food Policy & City of Melbourne, 2014 \\
\hline Mexico City & Aliméntate; Comedores Comunitarios & MUFPP, 2015b \\
\hline Milano & Food Policy Milano & $\begin{array}{l}\text { Città Metropolitana di Milano, } \\
2015\end{array}$ \\
\hline Montreal & $\begin{array}{l}\text { Plan de développement Système Alimentaire } \\
\text { Montréalais } 2025\end{array}$ & Cré de Montreal, 2015 \\
\hline Nairobi & Nairoby Urban Food Bill: Nairobi fresh & Nairobi City County, 2014 \\
\hline New York & FoodWorks & $\begin{array}{l}\text { The New York City Council, } \\
2013\end{array}$ \\
\hline Paris & Plan alimentation durable & Mairie de Paris, 2015 \\
\hline Pittsburgh & Pittsburgh Food policy Council website actions & $\begin{array}{l}\text { Pittsburgh Food Policy Council, } \\
2016\end{array}$ \\
\hline Quito & AGRUPAR & MUFPP, 2015b \\
\hline Rotterdam & Food \& The City & City of Rotterdam, 2012 \\
\hline
\end{tabular}




\begin{tabular}{|l|l|l|}
\hline Riga & Getlini EKO & MUFPP, 2015b \\
\hline San Francisco & San Francisco Healthy and Sustainable Food Policy & $\begin{array}{l}\text { San Francisco Department of } \\
\text { Public Health, 2010 }\end{array}$ \\
\hline Sao Paulo & $\begin{array}{l}1^{\circ} \text { Plano Municipal de segurança alimentar e } \\
\text { nutricional 2016-2020 }\end{array}$ & $\begin{array}{l}\text { Prefeitura do Município de São } \\
\text { Paulo, 2016 }\end{array}$ \\
\hline Toronto & Toronto Food Strategy & Toronto Public Health, 2010 \\
\hline Torino & $\begin{array}{l}\text { Towards the Turin Food Policy. Best Practices and } \\
\text { visions }\end{array}$ & Città di Torino, 2016 \\
\hline Utrecht & Lekker Utregs & Lekker Utregs Website, 2012 \\
\hline Vancouver & What feeds us: Vancouver food strategy & City of Vancouver, 2013 \\
\hline
\end{tabular}

All of the selected policy documents were provided with a list of the relevant actions Cities engage in. Thus, while the policies are the comprehensive plan and political documents, the actions are the activities, operations, and practical goals. Each action was analysed and then coded according to the "Framework for Action" provided by the MUFPP (MUFPP, 2015a). The MUFPP Text provides six main action categories that detailed recommended actions are associated with (Table 2). For each city's policy, the main purpose of the actions was identified and then categorised according to the MUFPP framework.

\begin{tabular}{|c|c|c|}
\hline Main topic & Recommended Actions & Code \\
\hline \multirow{6}{*}{$\begin{array}{l}\text { Ensuring an } \\
\text { enabling } \\
\text { environment for } \\
\text { effective action } \\
\text { (governance) }\end{array}$} & Facilitate collaboration across city agencies and departments & G1 \\
\hline & Enhance stakeholder participation and Food Councils & G2 \\
\hline & Identify, map and evaluate local initiatives & G3 \\
\hline & Develop or revise urban food policies and plans & G4 \\
\hline & Develop or improve multisectoral information systems & G5 \\
\hline & Develop a disaster risk reduction strategy & G6 \\
\hline \multirow{7}{*}{$\begin{array}{l}\text { Sustainable } \\
\text { diets and } \\
\text { nutrition }\end{array}$} & Promote sustainable diets & $\mathrm{N} 1$ \\
\hline & Address non-communicable diseases associated with poor diets and obesity & $\mathrm{N} 2$ \\
\hline & Develop sustainable dietary guidelines & $\mathrm{N} 3$ \\
\hline & $\begin{array}{l}\text { Adapt standards and regulations to make sustainable diets accessible in public } \\
\text { sector }\end{array}$ & $\mathrm{N} 4$ \\
\hline & Explore regulatory and voluntary instruments in private companies & N5 \\
\hline & Encourage joint action by health and food sectors & N6 \\
\hline & Commit to achieving universal access to safe drinking water and & $\mathrm{N} 7$ \\
\hline \multirow{6}{*}{$\begin{array}{l}\text { Social and } \\
\text { economic } \\
\text { equity }\end{array}$} & Social protection actions to improve food access (i.e. food banks) & S1 \\
\hline & Reorient school feeding programmes & $\mathrm{S} 2$ \\
\hline & Promote decent employment for all & S3 \\
\hline & Encourage and support social and solidarity economy activities & S4 \\
\hline & Promote local networks and support grassroots activities & S5 \\
\hline & Promote participatory education, training and research & S6 \\
\hline \multirow{6}{*}{$\begin{array}{l}\text { Food } \\
\text { production }\end{array}$} & Promote and strengthen urban and peri-urban food production & P1 \\
\hline & Seek coherence between the city and nearby rural food production & $\mathrm{P} 2$ \\
\hline & Apply an ecosystem approach in land use planning and management & P3 \\
\hline & Protect and enable secure access and tenure to land & $\mathrm{P} 4$ \\
\hline & Help provide services to food producers in and around cities & P5 \\
\hline & $\begin{array}{l}\text { Support short food chains, producers' organization, producer-to-consumer } \\
\text { networks and platforms }\end{array}$ & P6 \\
\hline
\end{tabular}




\begin{tabular}{|c|l|c|}
\hline & Improve (waste) water management and reuse in agriculture & P7 \\
\hline \multirow{5}{*}{$\begin{array}{c}\text { Food supply } \\
\text { and distribution }\end{array}$} & Assess the flows of food to and through cities (CO2) & D1 \\
\cline { 2 - 3 } & $\begin{array}{l}\text { Support improved food storage, processing, transport and distribution } \\
\text { technologies and infrastructure linking peri-urban and near rural areas (food } \\
\text { flow) }\end{array}$ & D2 \\
\cline { 2 - 3 } & Assess, review and/or strengthen food control systems & \\
\cline { 2 - 3 } & Review public procurement and trade policy & D3 \\
\cline { 2 - 3 } & $\begin{array}{l}\text { Provide policy and program support for municipal public markets, retailers and } \\
\text { other space of marketing }\end{array}$ & D5 \\
\cline { 2 - 3 } & Improve and expand support for infrastructure & D6 \\
\cline { 2 - 3 } & Acknowledge the informal sector's contribution & D7 \\
\hline \multirow{5}{*}{ Food waste } & Convene food system actors to assess and monitor food loss and waste reduction & W1 \\
\cline { 2 - 3 } & Raise awareness of food loss and waste & W2 \\
\cline { 2 - 3 } & Research and collaboration on waste management & W3 \\
\cline { 2 - 3 } & $\begin{array}{l}\text { Save food by facilitating recovery and redistribution for human consumption of } \\
\text { safe and nutritious foods }\end{array}$ & W4 \\
\hline
\end{tabular}

Table 2 Topic and Recommended Actions (for a complete description of the Actions see MUFPP, 2015a)

The result was a dichotomy matrix, in which it was indicated whether the City had envisaged or not (1/0) a MUFPP recommended action.

4 The sample was then further analysed. The Shannon Entropy Index $(H)$ is calculated here to assess the degree 5 of dispersion of cities' actions (1).

$6 \quad H=-\sum_{i=1}^{n} p_{i} \ln p_{i}$

$9 \quad p_{i}=\frac{n_{i}}{N}$

where $n$ is the number of actions and $p_{i}$ is the probability that the action $i$ will appear, calculated by the amount of actions $N$ conducted by cities, and thus

When values are proximal to 1, the city will have an equal proportion of actions and it is well differentiated; when values are proximal to 0 , the city's food actions are less differentiated.

\subsection{Network Analysis}

The network between the cities is built on the coded actions they have in common. In this study, the network analysis and community detection were conducted using the "igraph" package of the R software 3.2.3.

\subsubsection{Network development}

In graph theory, a network is composed of a set of nodes or vertices connected through lines or edges. When the nodes are of the same kind, the networks are called "one-mode network"; when they are composed of two 
1 kinds of nodes, they are called "two-mode networks" (Borgatti and Everett, 1997). In discourse network

2 analysis, networks are built upon two types of nodes: the first is typically the actors, and the second is typically

3 the ideas they share (Leifeld, 2017). In the case of our analysis the first type is the cities and the second is the

4 recommended actions, as shown in Table 2. In the case of two-mode networks, the network analysis can be

5 conducted by transforming the two-mode network into a one-mode network, through the creation of an

6 adjacency matrix. In such a matrix the proximity between the first type of nodes, and thus their connection, is

7 defined by the number of second type nodes they have in common. In our case the ties between the cities - the

8 first type of node - is defined by the number of the recommended actions - the second type of node - they

9 have in common. In this process, a weight $w$ is assigned to each network relation, which is a function of the amount of shared recommended actions between the two cities, and it measures the strength of the link between them: the more actions cities have in common, the stronger their relations will be. Thus, the network becomes a one-mode, weighted, undirected network, with 32 nodes and 422 connections (Fig.1).

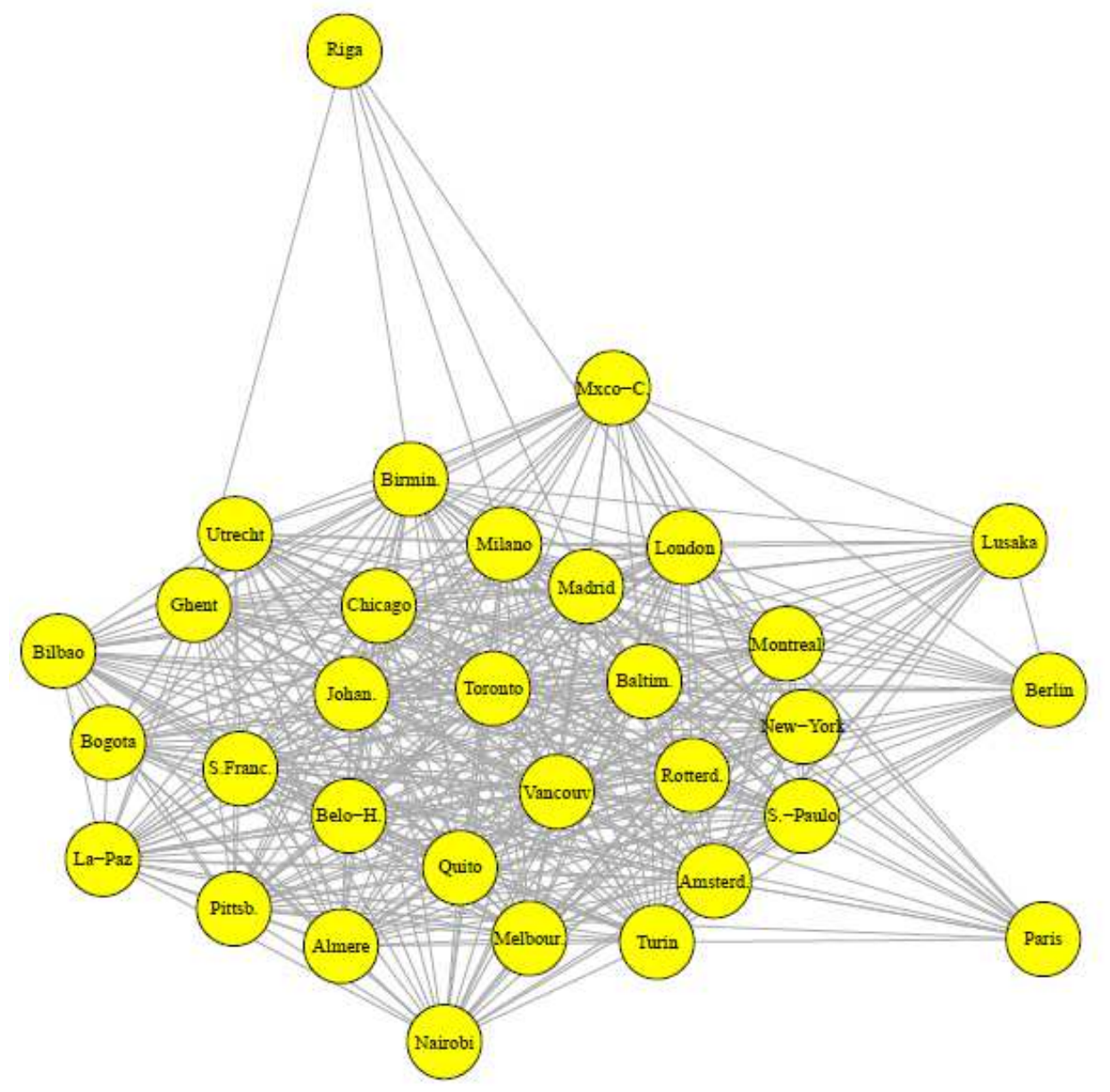


1 During the network development, a filter was applied in the network to weights greater than four $(w>4)$, so 2 only the relevant connections between cities are considered in the analysis. Thus, all the edges between cities 3 with a weight - the number of actions in common- lower than four have been excluded in the graph construction. This enables the outliers to be identified.

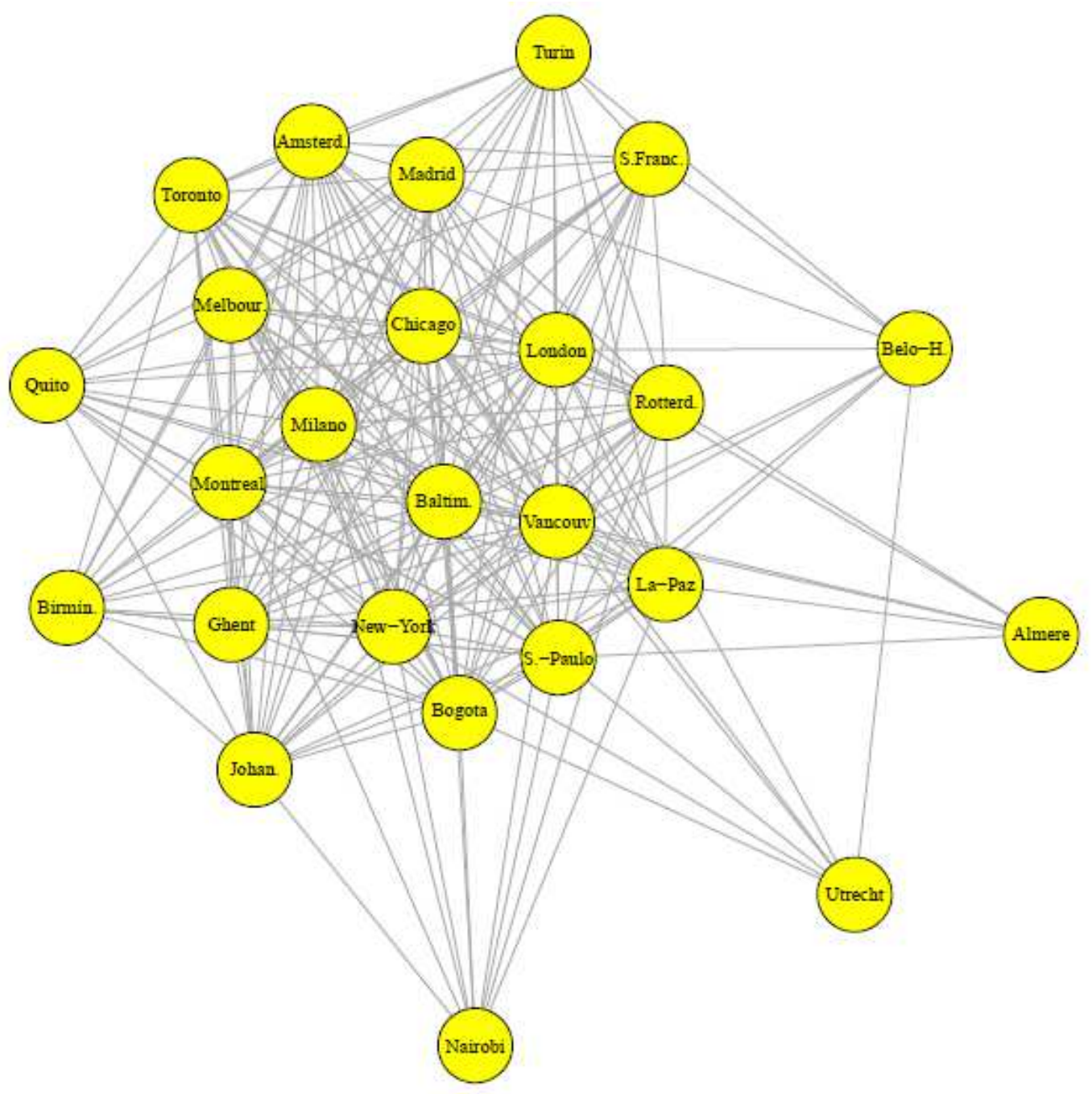

7 The final sample is thus composed of 25 cities/nodes and 204 connections (Fig. 2). The cities excluded are 8 Berlin, Bilbao, Lusaka, Mexico City, Paris, Pittsburgh and Riga. To describe the network structure we used 9 the density measure and the nodes' degrees. The density $\Delta_{G}$ provides a measure of the overall connectivity of the network and is calculated as the ratio between the actual number of edges $E$ between the nodes $n$ in a network, and the maximum number of ties that are possible. An undirected network is calculated as (2)

$12 \Delta_{G}=\frac{2 E}{n(n-1)}$ 
1 This ranges from 0 to 1 ; completed connected networks have a density score equal to 1 , while sparse networks

2 have a density score of 0 . This provides a measure of the probability that two nodes are directly connected.

3 The degree $d$ is the number of ties connected to each node, and therefore measures the centrality of the nodes

4 in the network (Freeman, 1978).

\subsubsection{Community detection}

6 In network analysis, a community is defined as a group of densely connected nodes with fewer connections across groups (Fortunato, 2010). Different methods can be used to detect communities (for a complete review see Fortunato, 2010). The Spinglass Community detection function (Reichardt and Bornholdt, 2006) calculates

9 iteratively the pairs of nodes that should be in the same group by considering their weights, which is typical of 10 a bipartite graph (Fortunato, 2010). This method has been confirmed in the literature to be the most appropriate 11 for small samples (Yang et al., 2016).

To validate the goodness of the community division we also compared the "intra-cluster density" and "intercluster density" for each cluster as previously found in the literature (i.e. Fisher et al., 2013) and as specified by Fortunato (2010). Considering a community $C$ of a graph $G$, with $|C|=n_{c}$ and $|G|=n$, the "intra-cluster density" $\Delta_{\text {int }}$ is defined as the ratio between the edge density inside a community and its potential edge density (Fortunato, 2010). For weighted networks, this is calculated as the sum of the weights $S$ of all the edges of the group $C$ divided by the number of binary links that are theoretically possible (Fisher et al., 2013) (3).

$18 \Delta_{i n t(c)}=\frac{s_{i n t}}{n_{c}\left(n_{c}-1\right) / 2}$

Following Fortunato (2010), the "inter-cluster density" $\Delta_{\operatorname{ext}(c)}$ is the ratio between the number of edges running from the vertices of a cluster and the maximum number of inter-cluster edges that is possible. For weighted networks, it is thus calculated as the ratio between the sum of the weights of inter-cluster edges of the group nodes $S_{\text {ext }}$ by the maximum number of binary links of the group's nodes and the rest of the nodes that are theoretically possible (4).

$\Delta_{\text {ext }(c)}=\frac{s_{\text {ext }}}{n_{c}\left(n-n_{c}\right)}$ 
1 According to the literature, for $\mathrm{C}$ to be a community, we expect $\Delta_{\operatorname{int}(c)}$ to be greater than the weighed density

2 of the graph G $\Delta_{G w}$, and $\Delta_{\text {ext (c) }}$ to be lower than the average density (Fortunato, 2010).

3 Finally, to verify the relationship between communities, we calculated the "between group density" (Fisher et al., 2013) $\Delta_{b e(c 1 c 2)}$ as the sum of the weights of the links between two communities $S_{b e}$, and the potential number of binary links between groups $C_{1}$ and $C_{2}(5)$.

$6 \quad \Delta_{b e(c 1 c 2)}=\frac{S_{b e}}{n_{c 1} n_{c 2}}$

If the density is high within a group its internal coherence is high, indicating discourse coalition. The lower the density between the communities, the more they will be polarized.

\section{Results}

The results are for both the samples of cities and the network resulting from the analysis. Table 1 shows the values of the Shannon Entropy Index $(\mathrm{H})$, thus identifying the diversification of the policy. Figure 3 shows the total percentage of actions cities are engaged in in terms of the six topics, and thus Figure 3 also shows the importance of the six MUFPP pillars. By comparing the two results, four scenarios can be observed. First, the cities with the higher number of actions have also higher scores on the Shannon Entropy Index. This is the case for cities such as Milan, which includes almost $60 \%$ of the MUFPP actions in its food policy and has a higher $H$ Index $(H=0.77)$, London (54\% of actions and $H=0.77)$, and New York (51\% of actions and $H=$ 0.73). These cities have thus incorporated most of the MUFPP actions in absolute terms and also have a good differentiation of actions. Second, other cities have lower Shannon Entropy scores even though they have a large number of actions (Figure 3), such as Vancouver $(H=0.68)$ or Chicago $(H=0.63)$ (Table 3), thus suggesting greater specialization. Figure 3 shows that Vancouver includes 54\% of the MUFPP, but it does not appear to apply actions in the same proportion, and is more focused on governance and production. Chicago is very concerned about nutrition, but it has not implemented actions on waste management. Third, cities as Ghent, Melbourne and Madrid have a high level of action differentiation $(H=0.74)$, even though they implemented around $35 \%$ of actions, showing that they have a more holistic approach in their food policies. In fact, they have planned actions from all the six pillars (Fig. 3). Finally, the cities with lower percentage of 
1 actions have also the lowest Shannon Entropy, including Berlin, Bilbao, Lusaka, Mexico City, Paris, Pittsburgh 2 and Riga.

3

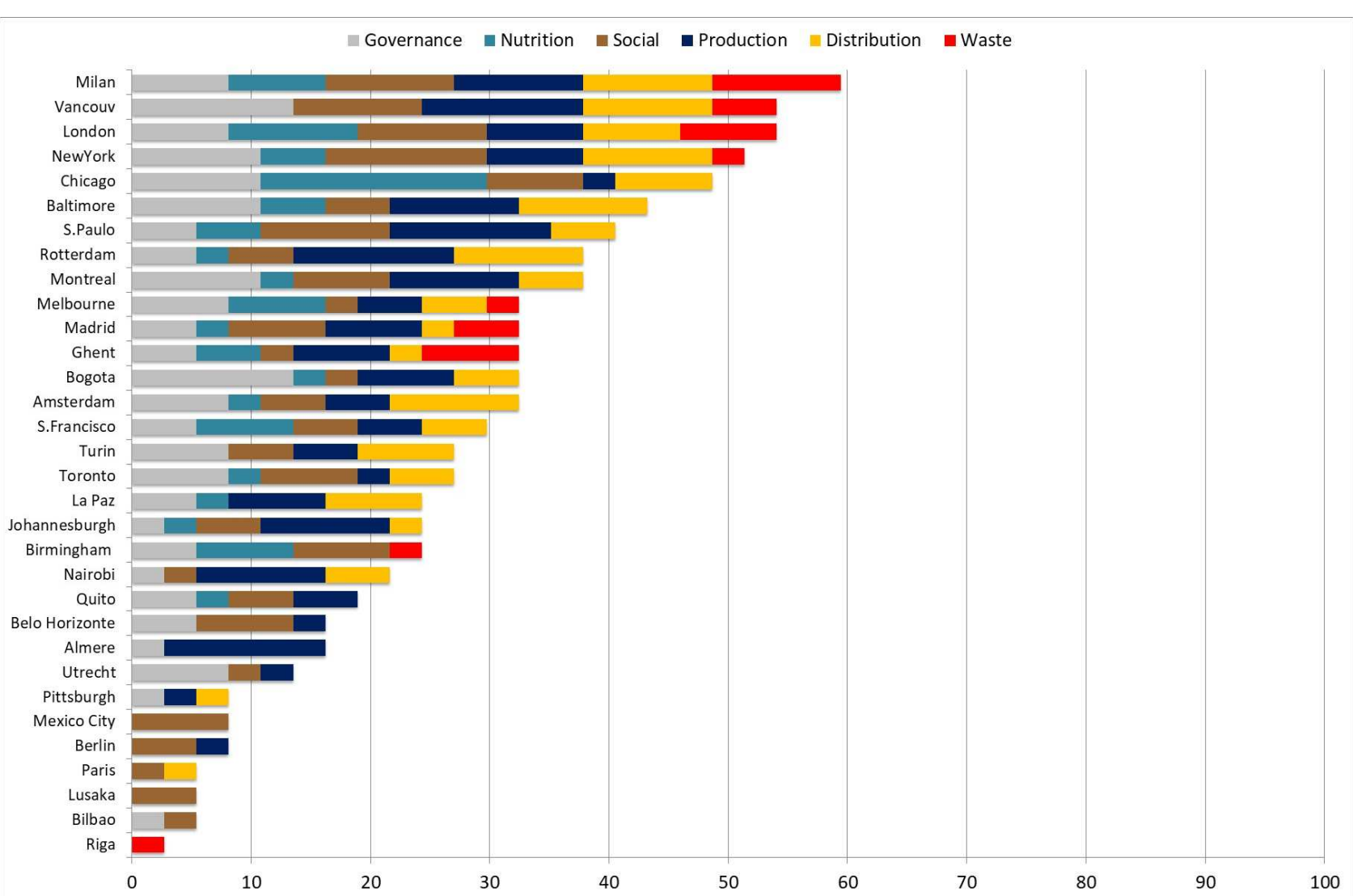

Table 3 Shannon Entropy index $(H)$

\begin{tabular}{ll}
\multicolumn{1}{c}{ City } & \multicolumn{1}{c}{$\boldsymbol{H}$} \\
\hline Milan & 0.77 \\
\hline London & 0.77 \\
\hline Ghent & 0.74 \\
\hline Melbourne & 0.74 \\
\hline Madrid & 0.74 \\
\hline New York & 0.73 \\
\hline San Francisco & 0.69 \\
\hline Vancouver & 0.68 \\
\hline Baltimore & 0.68 \\
\hline San Paulo & 0.66 \\
\hline Amsterdam & 0.66 \\
\hline Montreal & 0.66 \\
\hline Toronto & 0.65 \\
\hline Rotterdam & 0.64 \\
\hline Chicago & 0.63
\end{tabular}




\begin{tabular}{ll}
\hline Johannesburg & 0.62 \\
\hline Bogotà & 0.62 \\
\hline Turin & 0.59 \\
\hline Quito & 0.59 \\
\hline Birmingham & 0.57 \\
\hline La Paz & 0.57 \\
\hline Nairobi & 0.53 \\
\hline Pittsburgh & 0.48 \\
\hline Belo Horizonte & 0.44 \\
\hline Utrecht & 0.41 \\
\hline Bilbao & 0.30 \\
\hline Paris & 0.30 \\
\hline Berlin & 0.28 \\
\hline Almere & 0.20 \\
\hline Lusaka & 0.00 \\
\hline Mexico City & 0.00 \\
\hline Riga & 0.00
\end{tabular}

These are also the cities excluded from the final sample during the network analysis. Most appear to have applied just one or only a few recommended actions (i.e. Berlin, Paris, Riga), or have just started a process of consultation with private and public bodies (i.e. Bilbao). This result confirms that the most relevant cities are 5 considered in the network.

6 Three recommended actions were not associated with food policies: "Seek coherence between the city and 7 nearby rural food production" (P2), "Improve and expand support for infrastructure" (D6) and "Acknowledge 8 the informal sector's contribution" (D7).

9 Most of the actions envisaged by cities concern governance, particularly "G2 - Enhance stakeholder participation and Food Councils" and "G4 - Develop or revise urban food policies and plans", which were included by over $50 \%$ of cities, followed by actions concerning production, such as "P1 - Promote and strengthen urban and peri-urban food production" and "P4 - Protect and enable secure access and tenure to 13 land"; social equity, such as "S5 - Promote local networks and support grassroots activities" (46\%); 14 distribution action, such as "D5 - Provide policy and program support for municipal public markets, retailers 15 and other space of marketing" (43\%), and "N1 - Promote sustainable diets nutrition", (43\%). The most marginal actions in governance are "G6-Develop a disaster risk reduction strategy" (5\%); in nutrition "N7- 
1 Commit to achieving universal access to safe drinking water" (5\%); in production "P7 - Improve (waste) water

2 management and reuse in agriculture" (8\%); and in general waste management actions.

3 In Figure 4 the line width represents the number of actions in common between the cities - the weight, while

4 their size is a function of their degree $d$ centrality. Among the cities, Vancouver is the most related with other

5 cities, with a $d=23$, followed by New York, San Paulo, and London $d=22$, while Almere is the least 6 connected with $d=6$.

7

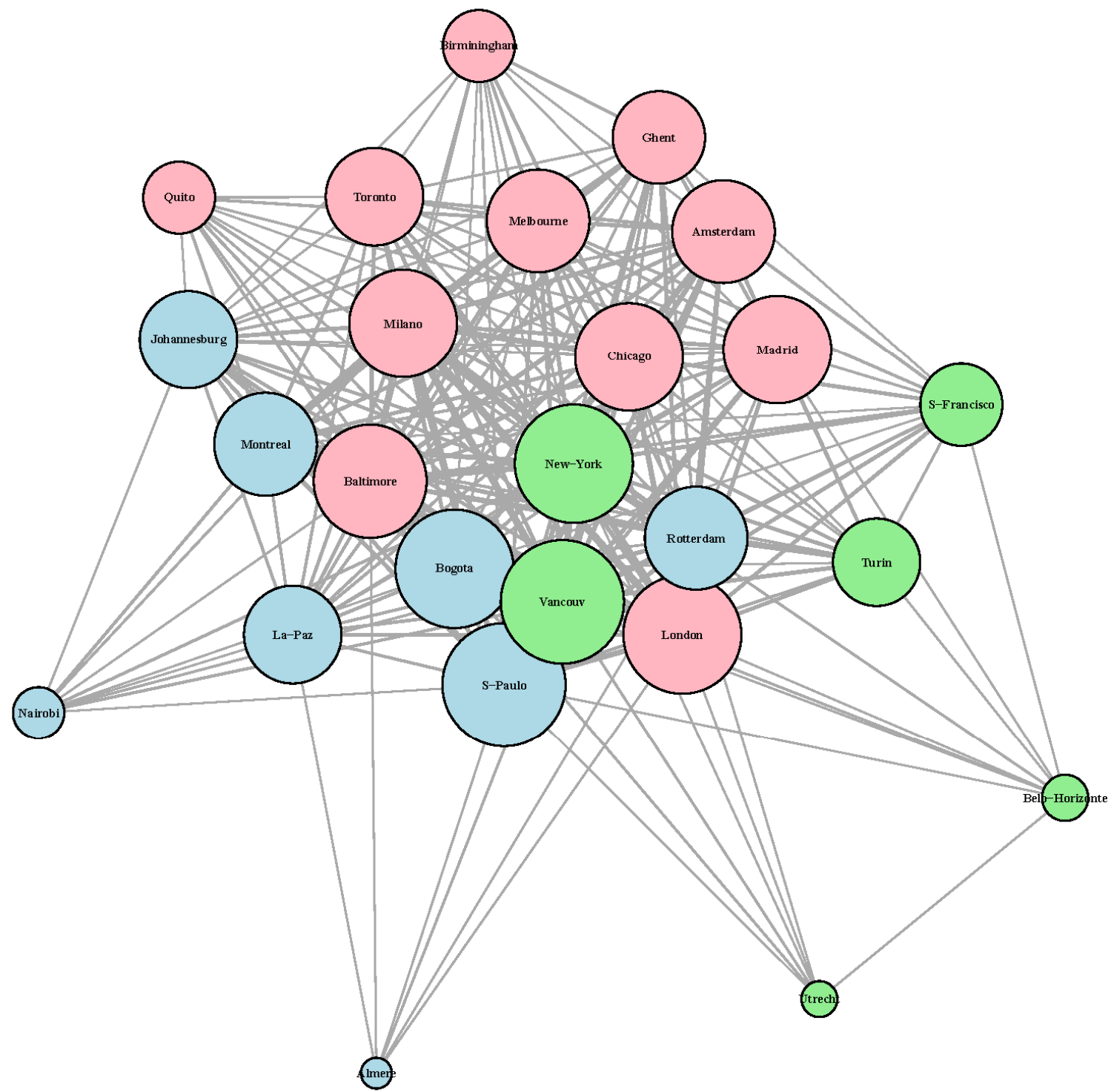

Figure 4 The Clusters resulting from the Spinglass community detection algorithm

9 The network has a high density score $\Delta_{G}=0.75$, which indicates that the nodes are highly connected in the network. As we have selected edges with a $w<4,75 \%$ of the cities of our sample have at least four actions in 
common. The assorted colours indicate the different clusters the cities belong to. The community detection

2 algorithm has in fact detected three cities' clusters (Table 4). As shown, the internal density $\Delta_{i n t(c)}$ and the 3 external density $\Delta_{\operatorname{ext}(c)}$ are always respectively higher and lower than the weighted density of the network

$4 \Delta_{G w}$ and higher and lower than the density between groups $\Delta b e$, confirming the validity of the cluster division

5 (Table 5). The "between groups density" indicates a higher density between Groups 2 and 3, while Groups 1

6 and 2 appear to be more distant (Table 5).

7

\begin{tabular}{|c|c|c|c|}
\cline { 2 - 4 } \multicolumn{1}{c|}{} & $\begin{array}{c}\text { G1. Agriculture for food } \\
\text { security }\end{array}$ & $\begin{array}{c}\text { G2. Governance and food } \\
\text { economy }\end{array}$ & $\begin{array}{c}\text { G3. Sustainable and healthy } \\
\text { consumption }\end{array}$ \\
\hline Cities & Almere & Belo Horizonte & Amsterdam \\
& Bogota & New York & Baltimore \\
& Johannesburg. & San Francisco & Birmingham \\
& La Paz & Turin & Chicago \\
& Montreal & Utrecht & Ghent \\
& Nairobi & Vancouver & London \\
& Rotterdam & & Madrid \\
& San Paulo & & Melbourne \\
& & & Milan \\
& & & Quito \\
& & & Toronto \\
\hline$\Delta_{\text {int }(\boldsymbol{c})}$ & 5.25 & 6.46 & 7.78 \\
\hline$\Delta_{\text {ext }(\boldsymbol{c})}$ & 2.37 & 2.64 & 2.18 \\
\hline
\end{tabular}

Table 4 Groups of cities

\begin{tabular}{|c|c|}
\hline$\Delta$ & Score \\
\hline$\Delta_{\boldsymbol{G W}}$ & 5.20 \\
\hline$\Delta_{\boldsymbol{b e}(\boldsymbol{c} 1 \boldsymbol{c} 2)}$ & 4.52 \\
\hline$\Delta_{\boldsymbol{b e}(\boldsymbol{c} 1 \boldsymbol{c} 3)}$ & 4.89 \\
\hline$\Delta_{\boldsymbol{b e}(\boldsymbol{c 2 c} \mathbf{c})}$ & 5.74 \\
\hline
\end{tabular}

Table 5 Values of weighted density

In the following paragraphs, details are given about the actions characterising each cluster.

\section{Group 1 - Agriculture for food security}

In this group, the cities address urban food security mainly through actions that sustain the food production of the local agriculture. Notably, all the cities are engaged in directly supporting urban and periurban agriculture (P1), which secures the supply of fresh and healthier food. With this action, cities typically associate the protection and securing of access and tenure to land (P4); the helping in the provision of services to food producers in and around cities (P5); the supporting of short food chains, producer organizations, and producerto-consumer networks (P6); and there are also several actions concerning the support of improved food storage, 
processing, transport and distribution technologies and infrastructure (D2). The group is unique as it includes cities that take action on local food safety and quality legislation and regulations (D3), and this attention to food quality is in accordance with the general attention to promoting healthy and sustainable diets (N1).

The sustaining and promotion of urban and periurban agriculture (P1) is for example conducted through actions that legally allow urban agriculture. In Nairobi, the City Council has issued a specific legal permit for urban agriculture (FAO, 2016; Nairobi City County, 2014). To prevent health risks, it has also included several rules on food safety such as hygienic standards, animal welfare and traceability (D3). The sustainability of urban and agricultural production is also done through the sustainability of local production, to enrich the local food supply. Montreal has the objective of standardising and diversifying the local production of food, by promoting its access to market (CRÉ de Montréal, 2014), both in periurban and urban areas, through dedicated events as the "Cultiver Montréal" or the dedicate website "MontrealAgriculture". The sustainability of agricultural production is often associated with policies for agricultural land preservation (P4), to ensure land for local production results in local consumption. The city of Nairobi has devised legal means to ensure vacant private land can be used for agricultural purposes, by contracting with the private owners (Nairobi City County, 2014). Through its "Inventario das zonas productivas" (Inventory of productive zones), La Paz aims to monitor what is produced, how it is produced and by whom, and it also verifies the potential food capacity of vacant land, distinguishing what is possible to produce in urban, periurban and rural lands (Ciudade de Nuestra Senora de La Paz, 2014). The provision of urban areas for growing in Almere is realised through the "Agromere project", set up "to explore opportunities to re-integrate agriculture into modern Dutch city life". A city district of 250 ha has been developed in which 70 ha are devoted to houses and infrastructure and 180 ha to agricultural production (The RUAF, 2011). The provision of services to farmers (P5) is done through technical assistance and tools and funds. In Johannesburg, seven "Agri-resource centres" have been implemented to empower urban farmers, which are aimed "to serve as community based support systems for agricultural activity at an individual/household and communal level" (City of Johannesburg Metropolitan Municipality, 2011: p.47) by organising training workshops, inter-sectoral collaboration forums, information and assistance about the access to land, cooperative registration, and providing productive inputs such as seeds and water licenses. In addition to the sustainability of the production, the cities also aim to sustain the link from producers to markets and consumers (P6). In San Paolo, "Do campo para cidade" (From the field to the city) aims to implement markets 
1 for family farms in the city (Prefeitura do Município de São Paulo, 2016). In the "Plan Maestro de

2 Abastecimiento y Seguridad Alimentaria" Bogotà has implemented the "Agrored": rural production networks

3 among farmers and processors for organizing supplies (Alcadia de Bogotà, 2006). The city has also

4 implemented the "Nutrired", which is focused on improving food distribution (D2) by organising the supply

5 of food among urban actors and integrating local food processing, food handling, and the commercial management of all economic agents.

7 Cities belonging to Group 1 are almost all in developing countries. Except for Montreal and San Paolo, all the

8 cities have under $35 \%$ of actions implemented, and none have a food strategy that includes all the MUFPP

9 issues (Table 3). For example, none of these cities have adopted food waste strategies, and also Distribution

10 (D) and Nutrition (N) actions are strongly linked to the core issue of this group, which is the security of urban

11 production (Fig.3).

\section{Group 2 - Urban food system integration process}

13 The second cluster groups cities more focused on actions concerning governance, social equity and economic development. These cities are engaged in facilitating collaborations across agencies and departments (G1) and enhancing stakeholder participation (G2). They are also engaged in several aspects of the food system, from production (sustaining short food supply chains (P6)), to distribution (support of food flow (D2)), the support of different spaces of sale in the city (D5), the review of public procurement and trade policy (D4) and waste management (prevention of waste in the public and commercial sector (W3)). In the social dimension, actions directly concerning public food assistance and social protection systems are found (S1), along with the reorientation of school feeding programs (S2) and the support of economic activities that have a solidarity dimension (S4).

The governance approach of Belo Horizonte first focused on centralising all the programs connected to food in a unique municipal department, before developing a unique food strategy. Created in 1993, the Secretaria Municipal de Abastecimento (SMASAN) "allowed for an integrated thinking of the food system. It no longer was 'food for hungry students' in a department of education, or 'food for needy people' in a department of social assistance, or 'food for consumers' in a department of commerce, or 'food from family farmers' in a department of agriculture" (Rocha, 2016: 33). A multiscale approach is applied as "food systems exist at many scales, from household to neighbourhood, to city, to region and beyond" (City of Vancouver, 2013: 47). The 
city of Vancouver has thus envisaged the strengthening of alliances in its governance actions and partnering with other municipalities in the Metro Vancouver and Fraser Valley regions on food policy. All the cities have envisaged their participation in Food Policy Councils (G2). According to the Vancouver food strategy the "partnerships are an essential aspect of achieving the actions" of food policies (City of Vancouver, 2013: 49). Only by including and coordinating the different local stakeholders it is possible "to make the biggest impact on food system issues", because "that makes the most of the tools and levers available to the City" (City of Vancouver, 2013: 53). Thus, the cities focus their policies on actions of governance with applications both "inside" the institutions (G1) and outside them, and for food system stakeholders (G2), while also implementing educational actions in schools and supporting solidarity actions.

This inclusive approach is also applied to waste management. Cities are interested in collaborating with the private sector in terms of research, and with educational and community-based organisations to prevent waste or safely recover food and packaging (W3). New York has contemplated actions such as discouraging bottled water consumption, the establishment of a voluntary household composting program, and the encouragement of restaurant grease recycling (The New York City Council, 2013).

In this group, there is special attention paid to distribution issues. Actions are aimed at improving the efficiency of distribution passages and food flow to secure food access in the city (D2). New York has planned to "identify optimal distribution routes and modes for food distribution within the region and city" (The New York City Council, 2013: 46), along with several actions that maximize the potential of the Hunts Point Food Distribution Centre (The New York City Council, 2013: 46), as well as diversifying and improving food transports. In this group, specific attention is paid to improving the efficiency of the marketing system through developing different spaces of sale (D5), such as farmers markets, retailers and processors. New York has envisaged actions to support food manufacturers such as specific training workshops, the creation of an online resource centre, and the development of new industrial space for food manufacture business. These actions go beyond the improvement of food access and aim to generate growth and employment in the food manufacturing sector (The New York City Council, 2013). In terms of actions addressed at public food procurement (D4), San Francisco has established the "Food Procurement Ordinance", by which "to ensure that a percentage of the City's direct food purchases support regional agricultural producers, the Department of the Environment was asked to draft a local and sustainable food procurement ordinance" (San Francisco City, 2010: 18). Attention 
1 is also paid to reorienting feeding programs in schools (S2) by improving the quality of meals provided. Turin

2 has implemented the project "Il menu l'ho fatto io" where the families were involved in the definition of a

3 healthy and sustainable school menu (Città di Torino, 2016). In the group, a significant number of actions

4 address social equity issues. Several cities have proposed food assistance actions such as food banks and community kitchens (S1). San Francisco has envisioned that it can maximize food stamps enrolment through a public internet interface. Some cities also have sustained solidarity economic activities (S4) as Belo Horizonte, where the "Popular Restaurant" is a cafeteria-style restaurant open to all, serving over 20,000 nutritious meals per day at subsidized prices. With this action, the policy also aims to incentivise the purchase of food directly from small-scale families (Rocha, 2016). "Abastecer" is a program in which selected grocery stores can sell vegetables at a price below the market value (Rocha, 2016). Finally, in this group of cities we find interest in actions that support short food supply chains (P6), such as CSA and other forms of direct farmers' sale. Turin has developed a label, the "Paniere dei prodotti tipici della Provincia di Torino" (Basket of typical products of the Province of Turin), which aims to facilitate the sale of local farmers' products in urban shops (Città di Torino, 2016).

All of the cities in this group are metropolitan urban areas.

\section{Group 3 - Sustainable and healthy consumption}

The third group is represented by cities that are engaged in actions promoting healthy diets and providing access to fresh food. These cities have developed actions concerning healthy diet promotion (N1), the involvement of private and public companies by regulatory and voluntary instruments (N5) and noncommunicable diseases (N2). The creation of Food Policy Councils (G2), and the involvement of different fundamental issues in the food policies of this cluster. The actions of healthy diet promotion (N1) are particularly aimed at children in schools through food education activities. In the Mayor Food Strategy, the City of London proposed to support the education system by increasing the amount of time spent on food education in schools, such as cooking activities, and also supports 
children about the value of agriculture and fresh food, Amsterdam and Chicago promote actions concerning community food gardens (S5) in schools (City of Chicago, 2013). Education actions are also aimed at adults: Quito organised the "Points of Healthy Stations" that addressed the basic health needs of citizens and gave them advices on healthy foods (MUFPP, 2016). With its "Thursday Veggie Day", the city of Ghent encourages the consumption of a tasty vegetarian dish at least once a week. As the consumption of meat is connected to obesity and climate change, with this action the city combines the promotion of a healthy diet with the environmental sustainability of the food system (Ghent Food Policy Council, 2013).

Chicago is a city that is more engaged with obesity and other diseases connected to poor diets (N3). It has planned to improve the collection of data on obesity using qualitative interviews and obesity-related indicators, in accordance with researchers, university and other organizations. It has also envisioned that it can strengthen the collaboration between the public health service and the department of economic development, to integrate health issues into local land planning projects (City of Chicago, 2013).

In addition to the direct actions of public bodies, several actions aim to "engage grocery chain as partners" (N5), to share the responsibility of healthy choices with the actors providing food in the urban dwellers' everyday lives. In Baltimore the "Get Fresh Kids Menu" action has led nine vendors to create healthy kid's menus, which meet school nutrition requirements and are offered in smaller portion sizes and at affordable prices (Baltimore City, 2014). The engagement of the cities in providing healthy options is realised through the efforts of supporting specific food businesses (D5) engaged in healthy food, with the aim of improving food desert areas. In Baltimore, the Baltimore Food Desert Retail Strategy aims to expand specific supermarkets, through the "Personal Property Tax Credit for Supermarket" which is a 10 -year, $80 \%$ personal property tax credit for supermarkets located in food desert areas. Among their obligations, supermarkets must have "at least 500 square feet dedicated to the sale of fruit and vegetables and at least 500 square feet dedicated to other perishable goods including meat, seafood and dairy products” (Baltimore City, 2016).

In terms of distribution, the analysis of food flows (D1) aims to secure food access that is healthy and environmentally sustainable. Amsterdam and its neighbouring provinces have started mapping the flow of food to overcome problems in the delivery of food (European Commission, 2008); the aim of the "Food Environment Map and Report" of Baltimore is to identify areas of greatest need; and Melbourne wants to 
1 identify opportunities to reduce the greenhouse gas emissions associated with the city's food consumption

2 (City of Melbourne, 2014).

3 In line with these policies, the support of community gardens and other grassroots activities (S5) occurs in the

"Huertos Saudable" in Madrid (Ajuntamento de Madrid, 2016). Urban gardens and food production can also create and increase employment (S3). In Ghent, the project "Heiveld: brownfields get a green touch" is an urban garden project that both promotes social employment and allows elderly inhabitants to share their gardening experiences (Ghent Food Policy Council, 2013). Another action aimed at improving the wellness of employees is the "Community Supported Agriculture (CSA) and Wellness" in Baltimore. Through this action the Managerial and Professional Society (MAPS) union incentivises CSA as part of employee wellness plans, by reimbursing employees that buy products from CSA with up to $\$ 250$ (Baltimore City, 2016). Finally, waste management actions can also be an opportunity to address food desert issues (W4). Ghent has promoted the "Ghent CPSW", which aims to redistribute food surplus from retailers and other sources to social organisations, to reach vulnerable people, improving food access, and at the same time reduce food waste. London appears to be the most active city in terms of waste management, addressing the concerns of private households, private companies and public agencies (London Development Agency, 2006).

These cities are very diverse in terms of the percentage of adopted actions and the degree of urban food strategy completeness in relation to MUFPP issues. The group includes Milan, with the highest Shannon index and Quito, with the lowest (Table 3).

\section{Discussion}

Our results confirm what previous research has suggested: there are differences in the policy frameworks (Coppo et al., 2017) and the Shannon Entropy Index shows that cities can be more or less specialized in terms of the six topics. We can identify two main groups: cities that have urgent needs and thus are forced to focus on priorities, for example with actions on nutrition to fight against obesity, or actions on food production to allow urban dwellers to grow their own food; and cities that have a more holistic approach, and choose to implement a wide range of food policy actions. In the last group, Milan is the most representative and its Urban Food Policy was recognized as the most innovative at the Guangzhou International Award 2018 (MUFPP, 2018). 
In general, production, social equity and governance issues are the most implemented actions in cities' plans and are closely connected to the social and economic dimensions of food production and consumption. Conversely, food waste actions are poorly represented in our sample, suggesting less interest in the environmental sphere of the urban food system. Waste management is a very expensive and complex issue and perhaps cities still consider the environmental aspect of food waste less urgent than productive and the social aspects. As the literature suggests, less attention is focused on environmental links to climate change (Reynolds, 2009). If "the only food system to be secure is that which is sustainable, and the route to food security is by addressing sustainability" (Lang and Barling, 2012: 322), the progress is required to better address the sustainability of the whole food system.

The high level of network density shows that cities' strategies are highly interconnected. This may be due to the common aims and instruments adopted by the cities and a "copying process", and in fact most of the cities have relatively recent food strategies and have been developed on the basis of the examples of other cities. Future studies should analyse the evolution of policies according to the specific context of the city.

Food production action, urban agriculture and nutrition security are linked, particularly in developing countries. Here, the need to ensure urban dwellers can grow their own food is combined with the need to implement food safety, as found in the literature and in case study analyses (De Bon et al., 2010). In Europe, urban agriculture is usually proposed as a response to land use change, to protect the original agricultural use (Ruggeri et al., 2017). According to Siegner et al. (2018), a major benefit urban agriculture provides to society is local environmental quality improvements, which is linked to the idea of multifunctional agriculture in urban-periurban areas (Zasada et al., 2011). Food production actions also encompass those that support the farmers in periurban areas, and thus support farming economies, particularly in Europe and in developing countries. Thus, these actions can benefit consumers by sustaining the activities of local food producers, which is similar to the findings in the literature on the link between farmers and urban food security. While in the past, farmers could increase their food production to feed more people, in a global market they do not have that power and now they are increasingly asked to produce in a more sustainable way, with fairer prices and direct connections with the local markets (Corsi and Mazzocchi, 2018). This is also similar to the literature suggesting that rethinking the urban-rural divide is required for sustainable urban development (Gren and Andersson, 2018). 
The analysis of the groups suggests that when cities are more engaged with governance actions they adopt a more holistic approach and consider more topics. Distribution issues and social equity relate particularly to more engagement in governance actions. According to the "New York Food Works", this is especially true for metropolises, where the complexities of the city justify the holistic approach: "When we buy a salad, we might not think about all the people and places that were involved in its creation" (The New York City Council, 2010: 1). This means that an UFP should consider all the steps between the production and the consumption of food as the distribution, the processing, and the waste management, and apply a multisector approach. Thus, cities are able to also include the "exchange nodes" of the food system, as wholesale markets, retailers, food hubs, distributors, and others that practically improve the process of the availability of food (Sonnino, 2014). Such a holistic approach is also applied in a constant dialogue with private and public bodies, local and regional actors, and by using Food Policy Councils (Feenstra, 2007). This reflects the ambition not only to design a sustainable urban development, but also to reorient the food system in a more sustainable way (Coppo et al., 2017; Candel, 2014).

It has been suggested that cities and local institutions adopt a coordinated policy framework to foster urban food security, but the debate has been abstract and generic, leading to a "simplistic view of governance" (Candel, 2014). From this perspective, Candel (2014) claimed that fragmented networks of institutional bodies can even have positive impacts: depending on the context, instead of applying a unique body of actions, a fragmented network may be more flexible to unexpected circumstances, and can better apply abilities and create space for variability and learning than a mono-centric governance system. In our sample, not all the cities have implemented a unique food policy. Again, UFP is a relatively new experience for several of the cities, so further studies should analyse the impact and the adaptation of the governance framework. In our opinion the organization of an UFP is a first step towards sharing an idea of a shared goal.

Our results suggest a trade-off between actions on food production and governance. It appears that cities more engaged in production, both in urban and periurban agriculture, are more focused on a few specialized actions, improving the capacity for growing food, the protection of agricultural land, and the connection between production and consumption. Particularly in developing countries, cities have not always adopted a unique food policy, while those with more governance actions have less actions in production, and in general a more comprehensive food plan. In developing countries, agricultural urban systems are historically strictly focused 
on enhancing food security in terms of availability (Gallaher et al., 2013), while in developed countries, cities need to govern the food supply to provide a more sustainable food system. Nevertheless, a more comprehensive vision of the urban food system for more sustainable urban development is also possible in developing countries (Smith, 1995).

Nutrition, governance and social equity are connected in developed countries and particularly in North America. Here we find cities in which a high wealth level has led to an increase of food diseases such as obesity. Actions addressing the demand side of food markets (Reynolds, 2009), are aimed at raising awareness among urban dwellers and the more vulnerable parts of the population about health issues and the consequences of food choices, and to securing consumer engagement (London Developement Agency, 2006). Particularly in US, the theme of food access has been combined with the urban vacant land issue, and implementing UA projects is often proposed to mitigate the food desert problem, (Smith et al., 2017). Some cities facing food insecurity connected to healthy diets have resisted "the temptation to reduce the urban food question to a narrow nutritional agenda" (Morgan, 2015: 2). The strategy is to integrate the issue of healthy food into the different aspects of social life, to prevent competition with other social issues such as jobs and social assistance, and to mobilise local resources (Mah and Thang, 2013). In the "Recipe for a Healthy place" the city of Chicago states that "the most effective way to address obesity and related diseases is to change the day-to-day environment so that it supports healthy eating" (City of Chicago, 2013: 1); in other words, to improve the eating habits of citizens food policies are needed to create a healthy place. A healthy place is a place where there is a new social life linked to community gardens and urban farming, a new economic development connected to more sustainable food system, and the capacity for distributing healthy food in areas where it is less accessible.

The literature has stressed the link between the alignment of local agriculture and healthy diets (Morrison, 2011). While in the policies, the identification of food deserts areas does occur, analysis of the local agriculture and the actions needed to reinforce such alignment is lacking.

\section{Conclusions}

The analysis has enabled three main issues to be identified in the current UFP actions: food production, the governance of the food system, and food health and nutrition. This first example of a worldwide UFP analysis 
covers policies both in developed and developing countries, from North America, Latin America, Africa, Europe and Australia. Although some cities are pioneers, UFP is currently a globally relevant issue, both in metropolises and middle-sized cities. UFPs encompass very different initiatives, coming both "from the bottom" and "from above" institutions. The MUFPP has attempted to frame UFPs, to define the path for adopting them, and to systematize actions conveying them into a single formal framework. The cities that signed the MUFPP are growing, confirming the that the sustainability of urban development must involve the urban food system. Although MUFPP has not been planned as a food security policy assessment, and its framework does not exclusively shape food security issues, according to the results it could provide an essential contribution to urban food security policy detection.

To conclude, urban food policies are "young" policies that arise from the very recent need for a reorganization of urban strategy, in response to the needs of the increasing urban population globally, and from the rapid globalization due to the liberalization of the market over the last thirty years (FAO, 2015). Thus, they have the spirit of innovation that often characterizes initial proposals for dealing with new challenges, but at the same time they lack organicity and homogeneity: thus, an instrument such as MUFPP and, more generally, the sharing of practices and knowledge is even more important for urban strategies needed to improve food security.

This worldwide analysis of food plans has revealed that while several cities have developed comprehensive policies including detailed actions, others have only developed general ideas on the main topics of food security. In addition, not always all the actions carried out by a city are included in a comprehensive food strategy, suggesting that such actions are isolated, or carried out without considering other public and private actions. This may allow more flexibility in public planning, but it can also lead to a serious dispersion of resources and effort. The MUFPP can be an important arena for more effective development.

We argue that our analysis can increase the knowledge and indirectly support the development of a network between cities, by providing another opportunity of exchange for the cities to sustain their future development. The analysis covered only the documents of the UFP and does not address in detail the actual application of the actions, in terms of money and practical engagement; further studies can investigate this further, and assess the short- and long-term impact of the actions envisaged by the cities. 


\section{References}

Ajuntamento de Madrid (2016). Alimentando otro modelo de ciudad. Available at : http://www.madrid.es/portales/munimadrid/es/Inicio/Actualidad/Noticias/Alimentando-otro-modelo-deciudad?vgnextfmt=default\&vgnextoid=1b4f38c001455510VgnVCM1000001d4a900aRCRD\&vgnextchanne l=a12149fa40ec9410VgnVCM100000171f5a0aRCRD

Alcadia Bogotà (2008). Plan Maestro de Abastecimiento de Alimentos para Bogotá PMASAB. Available at: http://www.alcaldiabogota.gov.co/sisjur/normas/Norma1.jsp?i=21063

Baltimore City (2016). Baltimore Food Policy Initiative (BFPI): Food System Priorities and Policies. Available at: http://www.baltimoresustainability.org/wp-content/uploads/2015/03/BFPI-Food-Systems-Priorities-andPolicies-12.02.16.pdf

Baltimore City (2014). Baltimore Food Policy Initiative. A Catalyst to Address Health, Economic and Environmental Disparities. Available at: http://www.baltimoresustainability.org/projects/baltimore-foodpolicy-initiative/

Battersby, J. (2013) Urban food security and climate change: A system of flow. In Climate Change Assets and Food Security in Southern African Cities. Earthscan, Abingdon. pp. 35-56.

Berlin Metropolis (2013). Strategie Stadtlandschaft. Natürlich urban produktiv. Available at: https://www.berlin.de/senuvk/umwelt/landschaftsplanung/strategie_stadtlandschaft/download/flyer.pdf

Besthorn, F.H. (2013) Vertical Farming: Social Work and Sustainable Urban Agriculture in an Age of Global Food Crises. Australian Social Work 66(2): 187-203.

Birmingham Food Council (2014). Birmingham Food Charter. Available at: http://www.birminghamfoodcouncil.org/wpcontent/uploads/2014/08/BirminghamFoodCharter_Summer2014 .pdf

Borgatti, S.P., and Everett, M.G. (1997). Network analysis of 2-mode data. Soc. Netw. 19, 243-269.

Bryld, E. (2003). Potentials, problems, and policy implications for urban agriculture in developing countries. Agriculture and Human Values 20(1): 79-86.

Brown, K.H., Carter, A. (2003) Urban agriculture and community food security in the United States: farming from the city centre to the urban fringe. Community Food Security Coalition, North American Urban Agriculture Committee. Available at: http://alivebynature.com/PrimerCFSCUAC.pdf

Candel, J. (2014). Food security governance: a systematic literature review. Food security 6(4): 585-601.

Città di Torino (2016). Towards the Turin Food Policy. Best Practices and visions. Available at: http://www.torinostrategica.it/verso-la-food-policy-di-torino/

Città Metropolitana di Milano (2015). Linee di indirizzo della Food Policy di Milano 2015-2020. Available at: http://mediagallery.comune.milano.it/cdm/objects/changeme:71246/datastreams/dataStream2902127992854 926/content?pgpath=/sa_siti_tematici/food_policy_milano/la_food_policy_di_milano/food-policy-milanovideo

City of Chicago (2013). A Recipe for Healthy Places. Available at: https://www.cityofchicago.org/content/dam/city/depts/zlup/Sustainable_Development/Publications/Recipe_F or_Healthy_Places/Recipe_for_Healthy_Places_Final.pdf 
City of Johannesburg Metropolitan Municipality (2011). Building our city. Building our future: End of Term Report $2011 \quad$ 2016. Available at: Available at: https://joburg.org.za/images/stories/2016/june/pdf/End\%20of\%20Term\%20Report.pdf

City of Melbourne (2014). Food City. City of Melbourne Food Policy. Planning for the future of our food. https://www.melbourne.vic.gov.au/SiteCollectionDocuments/com-food-policy.pdf

City of Rotterdam (2012). Food \& the City. Stimulating urban agriculture in and around Rotterdam. Available at: http://www.rotterdam.nl/Clusters/Stadsontwikkeling/Document\%202013/Groen/FoodTheCityEngels.pdf

City of Vancouver (2013). What feeds us: Vancouver Food Strategy. Available at: http://vancouver.ca/files/cov/vancouver-food-strategy-final.PDF

Ciudad de Nuestra Señora de La Paz (2014). Ley Municipal Autonómica No. 105. Ley Municipal Autonoma de Seguirdad Alimentaria. Available at: http://base.socioeco.org/docs/ley_20municipal_20aut_c3_b3noma_20de_20seguridad_20alimentaria_20no._ 201052014.pdf

Coppo G., Stempfle S. and Reho M. (2017). Urban food strategies and plans: considerations on the assessment construction. City Territory and Architecture. 4:8.

Corsi S., Mazzocchi Ch. (2019): Alternative Food Networks (AFNs): determinants for consumer and farmer participation in Lombardy, Italy. Agricultural Economics - Czech, 65.

Cré de Montreal (2014). Plan de développement d'un système alimentaire équitable et durable de la collectivité montréalaise (SAM 2025). Innover pour mieux se nourrir et se développer. Available at: http://sam.montrealmetropoleensante.ca/uploads/resources/files/document\%20complet\%20SAM\%202025.pd $\mathrm{f}$

De Bon, H., Parrot, L., Moustier, P. (2010) Sustainable urban agriculture in developing countries. A review, Agronomy for Sustainable Development, 30(1): 21-32

Dixon, J., Omwega, A.M., Friel, S., Burns, C., Donati, K., and Carlisle, R. (2007). The Health Equity Dimensions of Urban Food Systems. Journal of Urban Health 84(51): 118-129.

Doernberg, A., Zasada, I., Bruszewska, K., Skoczowski, B., and Piorr, A. (2016). Potentials and Limitations of Regional Organic Food Supply: A Qualitative Analysis of Two Food Chain Types in the Berlin Metropolitan Region. Sustainability, $8,1125$.

European Commission (2008). Amsterdam Food Strategy, The Netherlands. Available at: http://ec.europa.eu/regional_policy/archive/conferences/urban_rural/2008/doc/pdf/6a_iclei_amsterdam.pdf

Eurostat (2016). People at risk of poverty or social exclusion. Available at: http://ec.europa.eu/eurostat/statistics-explained/index.php/People_at_risk_of_poverty_or_social_exclusion

FAO. (2015) Growing Greener Cities in Africa: First Status Report on Urban and Peri-Urban Horticulture in Africa. Rome: Food and Agriculture Organization of the United Nations, 2012. Available at: http://www.fao.org/docrep/016/i3002e/i3002e.pdf FAO (2015) The State of Food Insecurity in the World. Available at: http://www.fao.org/3/a-i4646e.pdf

FAO (2016). Nairobi Fresh. Available at: http://www.fao.org/cfs/cfs-home/blog/blog- 
Feenstra, G. (1997). Local Food systems and sustainable communities. American Journal of Alternative Agriculture 12(1): 28-36.

Filippini, R., De Noni, I., Corsi, S., Spigarolo, R., Bocchi, S. (2018a). Sustainable school food procurement: What factors do affect the introduction and the increase of organic food? Food Policy 76: 109-119.

Filippini, R., Lardon, S., Bonari, E, Marraccini, e. (2018b) Unraveling the contribution of periurban farming systems to urban food security in developed countries. Agronomy for Sustainable Development 38 (2), 21

Fortunato, S. (2010). Community detection in graphs. Phys. Rep., 486: 75-174.

Freeman, L.C. (1978). Centrality in social networks conceptual clarification. Soc. Netw. 1:215-239.

Friel, S., Chopra, M., Satcher, D. (2007). Unequal weight: equity oriented policy responses to the global obesity epidemic. British Medical Journal, 335(7632): 1241-1243.

Gallaher, C.M., Kerr, J.M., Njenga, M., Karanja, N.K., WinklerPrins, A.M.G.A. (2013) Urban agriculture, social capital, and food security in the Kibera slums of Nairobi, Kenya, Agriculture and Human Values, 30(3): 389-404.

Gemeente Amsterdam, 2013. Voedsel en Amsterdam. Available at: http://www.amsterdam.nl/publish/pages/606807/voedselvisie_-_tekstversie.pdf

Ghent Food Policy Council, (2014). Gent En Gard Food Policy. From strategic to operational goals for the Gent en Garde food policy. Recommendations of the food policy council. Available at: http://www.ruaf.org/sites/default/files/Gent\%20en\%20Garde.pdf

Gren A. and Anderson E. (2018). Being efficient and green by rethinking the urban-rural divide-Combining urban expansion and food production by integrating an ecosystem service perspective into urban planning. Sustainable Cities and Society, 40, 75-82.

Hamilton, A.J., Burry, K., Mok, H.-F., Barker, S.F., Grove, J.R., Williamson, V.G. (2014) Give peas a chance? Urban agriculture in developing countries. A review, Agronomy for Sustainable Development, 34(1):45-73.

Horst, M.; McClintock, N.; Hoey, L. (2017). The Intersection of Planning, Urban Agriculture, and Food Justice: A Review of the Literature. Journal of American Planning Association 83, 277-295.

International Federation of Red Cross and Red Crescent Societies (2013) Humanitarian impacts of the economic crisis in Europe. Genf, Budapest: IFRC and RCS.

Lang, T., Barling., M. (2012) Food security and food sustainability: reformulating the debate. The Geographical Journal. 178(4): 313-326.

Moragues-Faus, A., Morgan, K. (2015) Reframing the foodscape: the emergent world of urban food policy. Environment and Planning A: Economy and Space. 47(5):

Leifeld, P., and Haunss, S. (2012). Political discourse networks and the conflict over software patents in Europe: political discourse networks. Eur. J. Polit. Res. 51: 382-409.

Lekker Utregs Website (2012). Lekker Utregs. Available at: http://www.lekkerutregs.nl/page/255/lekkerutregs.html

Macias, T. (2008) Working toward a just, equitable, and local food system: The social impact of communitybased agriculture, Social Science Quarterly, 89(5):1086-1101. 
Mah, C.L., and Thang, H. (2013). Cultivating Food Connections: The Toronto Food Strategy and Municipal Deliberation on Food. Int. Plan. Stud., 18:96-110.

Mairie de Paris (2015). Plan alimentation durable, 2015-2020. Available at: https://apisite.paris.fr/images/72882 Marsden, T., Sonnino, R. (2012). Human health and wellbeing and the sustainability of urban-regional food systems. Current Opinion in Environmental Sustainability Volume 4, Issue 4, October 2012, Pages 427-430.

Martin C, Evans J, Karvonen A, Paskaleva K, Yang D, Linjordet T, (2018). Smart-sustainability: A new urban fix?, Sustainable Cities and Society, https://doi.org/10.1016/j.scs.2018.11.028

Maxwell, D. (1999). The political economy of urban food security in Sub-Saharan Africa. World Development, 27(11): 1939-1953.

Mazzocchi C., Salvan M., Orsi L., Sali G. (2018). The Determinants of Large-Scale Land Acquisitions (LSLAs) in Sub-Saharan Africa (SSA): A Case Study. Agriculture, 8, 194.

McClintock N., Cooper J. and Khandeshi S. (2013). Assessing the potential contribution of vacant land to urban vegetable production and consumption in Oakland, California. Landscape and Urban planning 111, 4658.

Meenar M., Morales A. and Bonarek L. (2017). Regulatory Practices of Urban Agriculture: A Connection to Planning and Policy, Journal of the American Planning Association, 83:4, 389-403

Mekonnen, D.A., Gerber, N. (2017) Aspirations and food security in rural Ethiopia, Food Security, 9(2):371385.

Morgan, K. (2015). Nourishing the city: The rise of the urban food question in the Global North. Urban Stud. 52: 1379-1394.

Morrison KT, Nelson TA, Ostry AS (2011) Methods for mapping local food production capacity from agricultural statistics. Agr Syst 104: 491-499. doi: 10.1016/j.agsy.2011.03.006.

MUFPP - Milan Urban Food Policy Pact (2015a). Milan Urban Food Policy Pact. Available at: http://www.milanurbanfoodpolicypact.org/text

MUFPP - Milan Urban Food Policy Pact (2015b). Winning Practices from the cities of the Milan Urban Food Policy Pact. Available at: http://www.milanurbanfoodpolicypact.org/2016/10/14/milan-pact-awards-2016winners/

MUFPP - Milan Urban Food Policy Pact (2016). Activities in Bilbao. http://www.milanurbanfoodpolicypact.org/2016/07/25/activities-in-bilbao/

MUFPP - Milan Urban Food Policy Pact (2017). Signatories Cities. Available at: http://www.milanurbanfoodpolicypact.org/signatory-cities/

MUFPP - Milan Urban Food Policy Pact (2018). Milan Food Policy won Guangzhou Award 2018. Available at: $\quad$ http://www.milanurbanfoodpolicypact.org/2018/12/11/food-policy-of-milan-is-the-winner-of-theguangzhou-award-2018/

Nairobi City County (2014). The Nairobi City County Urban Agriculture Promotion and Regulation Bill. Available http://kenyalaw.org/kl/fileadmin/pdfdownloads/bills/2014/NairobiCityCountyUrbanAgricultureBill2014.pdf 
Obosu-Mensah, K. (2002). Changes in official attitudes towards urban agriculture in Accra. African Studies Quarterly, 6(3).

Opitz, I., Berges, R., Piorr, A., Krikser, T. (2015). Contributing to food security in urban areas: differences between urban agriculture and peri-urban agriculture in the Global North. Agric. Hum. Values, 32: 1-18.

Peters, C.J., Bills, N., Wilkins, J.H., Fick, G.H. (2008). Foodshed analysis and its relevance to sustainability. Renewable Agriculture and Food Systems, 24(1):1-9.

Pittsburgh Food Policy Council (2016). Annual Report 2014-2015. Available at: www.pittsburghfoodpolicy.org/.../PFPC_Annual_Report_2014-2015

Pothukuchi, K., and Kaufman, J.L. (1999). Placing the food system on the urban agenda: The role of municipal institutions in food systems planning. Agric. Hum. Values, 16: 213-224.

Prefeitura do Município de São Paulo (2016). $1^{\text {o }}$ Plano Municipal de Segurança Alimentar e Nutricional. Available at: http://www.prefeitura.sp.gov.br/cidade/secretarias/upload/trabalho/PLAMSANVERSAOFINALcompleta.pd $\mathrm{f}$

Raja, S., Born, B. and Kozlowski Russell, J. (2008). Transforming Food Environments, Building Healthy Communities, Planning Advisory Service (PAS) Report. Number 554. Chicago, American Planning Association.

Reichardt, J., and Bornholdt, S. (2006). Statistical mechanics of community detection. Physical Review E 74, 016110.

Rennkamp, B., Haunss, S., Wongsa, K., Ortega, A., and Casamadrid, E. (2017). Competing coalitions: The politics of renewable energy and fossil fuels in Mexico, South Africa and Thailand. Energy Res. Soc. Sci., 34:214-223.

Reynolds, B. (2009). Feeding a World City: The London Food Strategy. Int. Plan. Stud., 14: 417-424.

Rockson, G., Bennett, R., Groenendijk, L. (2013) Land administration for food security: A research synthesis, Land Use Policy, 32:337-342.

Rocha, C. and Lessa, I. (2009). Urban Governance for Food Security: The Alternative Food System in Belo Horizonte, Brazil. International Planning Studies, 14(4): 389-400.

Rocha, C. (2016). Belo Horizonte: the Opportunities and Challenges of Urban Food Security Policy. In Mark Deakin, M., Diamantini D., and Borrelli N. (eds.) The Governance of City Food Systems: Case Studies From Around the World. Fondazione Giangiacomo Feltrinelli, ISBN 978-88-6835-241-7.

Ruggeri, G., Mazzocchi, C., and Corsi, S. (2016). Urban Gardeners' Motivations in a Metropolitan City: The Case of Milan. Sustainability, 8:1099.

Saldanha, J. (2013). The coding manual for qualitative researchers. London: Sage

San Francisco Department of Public Health (2010). Executive Directive on Healthy and Sustainable Food 0903. Summary Report. Available at: http://sfgov.org/sffood//sites/default/files/Documents/sffood/FPC_Summary_Report_December_2010_final1 .pdf 
Segal, A. (2010). Food deserts: A global crisis in New York City causes, impacts and solutions. The Journal of Sustainable Development. J. Sustain. Dev., 3:197-214.

Siegner A., Sowerwine J. and Acey C. (2018). Does Urban Agriculture Improve Food Security? Examining the Nexus of Food Access and Distribution of Urban Produced Foods in the United States: A Systematic Review. Sustainability, 10.

Smith, D.W. (1995). Urban Food Systems and the Poor in Developing Countries. Transactions of the Institute of British Geographers, 23(2): 207-219.

Smith, G., Nandwani, D., Kankarla, V. (2017) Facilitating resilient rural-to-urban sustainable agriculture and rural communities, International Journal of Sustainable Development and World Ecology, 24(6):485-501.

Sonnino R. (2014) The new geography of food security: exploring the potential of urban food strategies: The new geography of food security. Geogr J. doi: 10.1111/geoj.12129.

Speak, S. (2015) To End Urban Hunger, Focus on Low-income Housing and Settlements in Cities. Global Policy. Available at: http://www.globalpolicyjournal.com/blog/26/05/2015/end-urban-hunger-focus-lowincome-housing-and-settlements-cities

Szabo S. (2016). Urbanisation and Food Insecurity Risks: Assessing the Role of Human Development. Oxford Development Studies, 44:1, 28-48.

The New York City Council (2013). FoodWorks A Vision to Improve NYC's Food System. Available at: http://council.nyc.gov/html/action/acpdfs/foodworks_report_update_2013.pdf

The RUAF Foundation (2011). Agromere: Integrating urban agriculture in the development of the city of Almere. Urban Agriculture magazine, 25. Available at: http://www.ruaf.org/sites/default/files/UAM\%2025Agromere\%2028-31.pdf

Tobin P., Schmidt N.M., Tosun J., and Burns C. (2018). Mapping states' Paris climate pledges: Analysing targets and groups at COP 21. Global Environmental Change, 48, 11-21.

Toronto Public Health (2010). Cultivating Food Connections: Toward a Healthy and Sustainable Food System for Toronto. Available at: http://tfpc.to/resources/agency/cultivating-food-connections-towards-a-healthyand-sustainable-food-system-for-toronto

UN (2011) Population Distribution, Urbanization, Internal Migration and Development: An International Perspective, Department of Economic and Social Affairs Population Division, Available at: http://www.un.org/esa/population/publications/PopDistribUrbanization/PopulationDistributionUrbanization. pdf

Viljoen A. and Wiskerke J.S.C. (2012). Sustainable food planning, evolving theory and practice. Wageningen Academic Publishers, Wageningen, Netherlands.

Walker S. (2016). Urban agriculture and the sustainability fix in Vancouver and Detroit, Urban Geography, $37: 2,163-182$.

WHO (2008). Our cities, our health, our future; acting on social determinants for health equity in urban setting. https://www.who.int/social_determinants/resources/knus_final_report_052008.pdf 
1 Wiskerke, J.S.C. (2009). On Places Lost and Places Regained: Reflections on the Alternative Food Geography 2 and Sustainable Regional Development. Int. Plan. Stud., 14: 369-387.

3 WVC (World Vegetable Centre), (2013). Peri-urban vegetable production promising young people Africa. 4 Available at https://avrdc.org/

5 Yang, Z., Algesheimer, R., and Tessone, C.J. (2016). A Comparative Analysis of Community Detection 6 Algorithms on Artificial Networks. Sci. Rep. 6. Article number: 30750.

7 Zasada, I. (2011). Multifunctional peri-urban areas - a review of societal demands and agricultural provision 8 of goods and services. Land Use Policy, 28(4), 639-648.

9 Zasada I., Schmutz U., Wascher D., Kneafsey M., Corsi S., Mazzocchi C., Monaco F., Boyce P., Doernberg 10 A., Sali G., Piorr A. (2017). Food beyond the city-Analysing foodsheds and self-sufficiency for different food 11 system scenarios in European metropolitan regions. City, Culture and Society, in press. 